\title{
A giant complex rectosigmoid bezoar with multiple foreign bodies: a first of its kind
}

\author{
Vinoth Boopathy, ${ }^{1}$ Mohnish Palaniswamy ${ }^{2}$
}

${ }^{1}$ Department of Medical Gastroenterology, Pondicherry Institute of Medical Sciences, Pondicherry, India

${ }^{2}$ Department of Radiology, Pondicherry Institute of Medical Sciences, Pondicherry, India

\section{Correspondence to} Dr Vinoth Boopathy, drbvinoth@gmail.com

Accepted 21 October 2014

\section{DESCRIPTION}

A 20 -year-old male patient presented with a 15 -day history of constipation, abdominal distention and abdominal pain. He was mentally impaired and would swallow foreign bodies, including pieces of clothing. His abdomen was firm and tender on examination with absent bowel sounds. Rectal examination revealed impacted stools. CT of the abdomen showed a $19 \times 26 \mathrm{~cm}$ ovoid intraluminal mixed density mass with mottled gas pattern and multiple foreign bodies occupying the rectosigmoid colon consistent with a bezoar (figures 1 and 2). Digital evacuation was performed several times and the bulk of the bezoar was removed piecemeal. The major bulk was cotton thread along with different objects such as pieces of bone, seeds of various fruits, stapler pins, buttons, metal wires, etc. These were removed. Finally the patient started passing stools on his own and was discharged. A bezoar is a tightly packed mass of foreign material in the gastrointestinal tract of humans or animals. Patients with learning disabilities and psychiatric illness have increased risk of bezoar formation due to

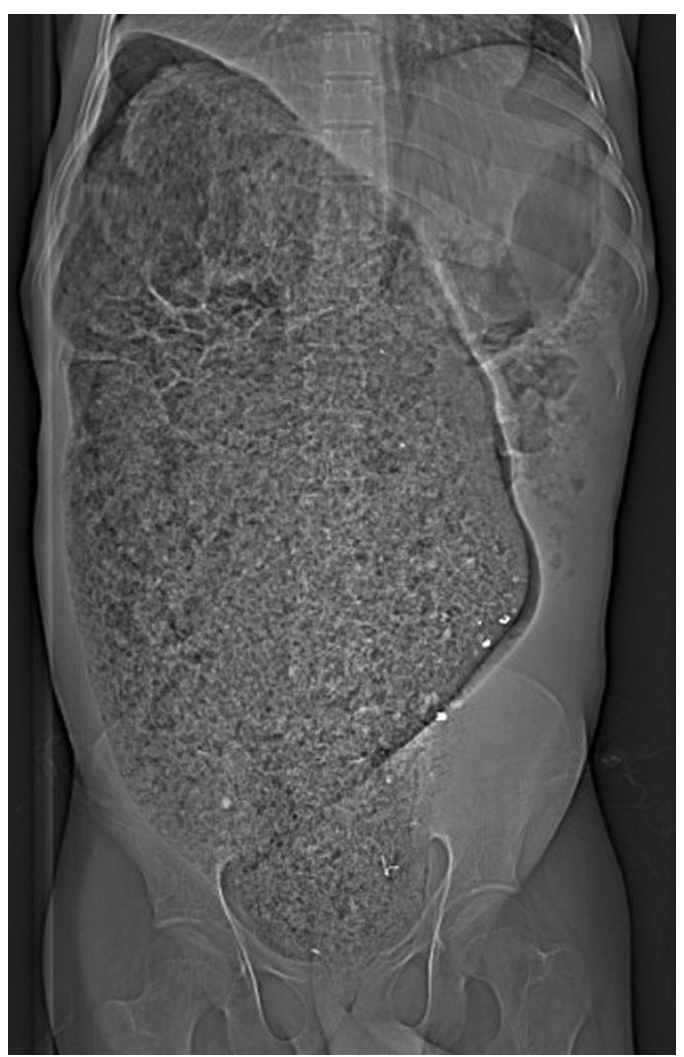

Palaniswamy M. BMJ Case Rep Published online: [please include Day Month Year] doi:10.1136/bcr-2014207573

CrossMark
Figure 1 Skiagram showing dilated bowel on the right side of the abdomen with mottled gas pattern along with multiple radio-opaque substances.

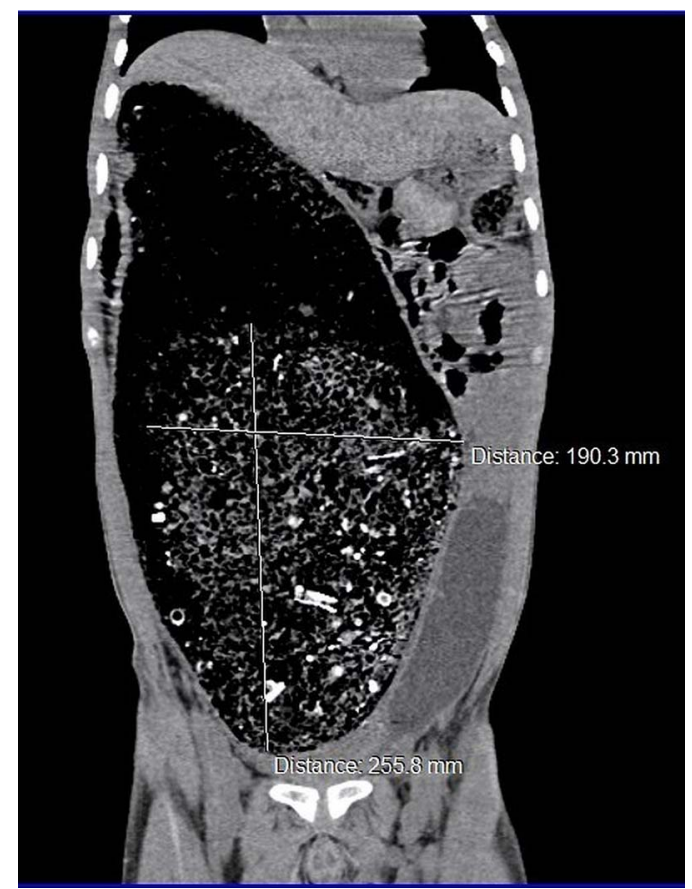

Figure $2 \mathrm{CT}$ of the abdomen showing dilated sigmoid and rectum with mottled gas pattern along with multiple radio-opaque foreign bodies consistent with a bezoar.

their abnormal dietary habits. ${ }^{1}$ A common site for a bezoar is usually the stomach; involvement of colon and rectum are rare. ${ }^{2} 3$ Our patient had irregular bowel habits since childhood and sometimes passed stools only once in 7-10 days, which over a period of time might have contributed to the development of the bezoar in the rectum. A giant complex bezoar of this size with multiple types of foreign bodies involving the rectosigmoid colon is very rarely reported.

\section{Learning points}

- History of dietary and bowel habits is extremely important in patients presenting with abdominal symptoms suggestive of intestinal obstruction.

- In a mentally disabled patient presenting with features of intestinal obstruction, the possibility of a bezoar should be considered.

Acknowledgements The authors would like to acknowledge Professor Authy in the department of general surgery for his help in the management of this case. 
Contributors VB was the treating physician and prepared the manuscript. MP helped in collection of the images and the literature review.

Competing interests None.

Patient consent Obtained.

Provenance and peer review Not commissioned; externally peer reviewed.

\section{REFERENCES}

1 Kuroki Y, Otagiri S, Sakamoto T, et al. Case report of trichobezoar causing gastric perforation. Dig Endosc 2000;12:181-5.

2 Manne JR, Rangu VM, Motapothula UM, et al. A crunching colon: rectal bezoar caused by pumpkin seed consumption. Clin Med Res 2012;10:75-7.

3 Mirza MS, Al-Wahibi K, Baloch S, et al. Rectal bezoars due to pumpkin seeds. Trop Doct 2009;39:54-5.

Copyright 2014 BMJ Publishing Group. All rights reserved. For permission to reuse any of this content visit http://group.bmj.com/group/rights-licensing/permissions.

BMJ Case Report Fellows may re-use this article for personal use and teaching without any further permission.

Become a Fellow of BMJ Case Reports today and you can:

- Submit as many cases as you like

- Enjoy fast sympathetic peer review and rapid publication of accepted articles

- Access all the published articles

- Re-use any of the published material for personal use and teaching without further permission

For information on Institutional Fellowships contact consortiasales@bmjgroup.com

Visit casereports.bmj.com for more articles like this and to become a Fellow 